\title{
REVIEW
}

\section{THE ACTUALIZATION OF THE CRITICAL IMPULSE IN CRITICAL THEORY: DIALOGICAL RATIONALITY AROUND RACHEL’S TOMB IN BETHLEHEM, PALESTINE}

\author{
RAMI K. ISAAC AND VINCENT PLATENKAMP \\ Centre for Sustainability, Tourism and Transport, Breda University of Applied Sciences, \\ Breda, The Netherlands
}

\begin{abstract}
In this review article, Isaac and Platenkamp argue that during the 1930s and 1940s of the previous century, concepts like "critical" and "essence" were still defined and understood in the tradition of what increasing numbers of academics called "Critical Theory." However, they suggest that since then the situation has significantly changed. In their view, while Critical Theory critically approaches the ideologies of the modern Western world, it has actually (itself) became a victim of this overwhelming critique of ideologies. To Isaac and Platenkamp, the main conceptualizations in and for Critical Theory have been weakened by a content inflation in the new historical phase of postmodernism. Thus, for instance, as a concept “criticism” had been revitalized to (down to?) a relativist position. In this review article, Isaac and Platenkamp suggest that academics in Tourism Studies now inherently claim to be "critical" by just appropriating the mere qualification critical, ipso facto. In this light, the old vital value of "Essence" thereby has become a superficial concept of old primitive ideologies, today, and it seems to have no meaningful function anymore in Tourism Studies. This review article thus aims to reintroduce the field of Tourism Studies to Marcuse's original concept of Essence and discuss it vis-à-vis its interpretational confrontation with the said postmodernist position and thereby to the very revitalization of the qualification "critical.” Hence, Isaac and Platenkamp seek to save this qualification from the postmodernist attacks on the universality of the Critical Theoretical position by drawing particular attention to Arendt's concept of the agora, viz. as that kind of public space (comparable to the forum Romanum), in which people significantly present themselves as individuals with independent opinions. In this regard, Isaac and Platekamp are particularly disturbed by the recent flowering of the so called "Critical Turn" group (or network) within Tourism Studies since it appears to progress without a thorough understanding of Critical Theory, per se. They argue that classical thinkers of Critical Theory need to be addressed and understood if the Critical Turn group of scholars in Tourism Studies may decently/faithfully/meaningfully be deemed to be critical. In order to make their case, Isaac and Platenkamp highlight the case of Rachel's Tomb in Bethlehem. They position the Tomb as a very important biblical tourism site (and agora) by and through which the revitalization of the "critical" may be incorruptibly recognized.
\end{abstract}

Key words: Agora; Rachel's Tomb; Bethlehem; Critical essence; Modes 1, 2, 3 


\section{Introduction}

Critical Theory has been referred to in tourism studies in a rather chaotic manner. An example of this disorder is the way Pritchard, Morgan, and Ateljevic (2011) referred to the value-laden discussion after a critical turn. They confused the distinction by Weber between value-laden research "Wertbezogenheit" and value-free research "Wertfreiheit” (Isaac \& Platenkamp, 2016). They presented value-laden research within the context of Critical Theory without realizing that their position was in accordance with Weber's value-free research. Higgins-Desbiolles and Whyte (2013) understood this very well. This discussion is symptomatic for the chaotic uneasiness in the use of Critical Theory after the Critical Turn in the tourism academy. Since the last generation of Critical Theorist, with Habermas (1984) being the most representative of them, some core elements in Critical Theory already have been seriously under attack. This already created some postmodern muddle within the tradition of Critical Theory itself. Relativism became dominant and made the Criterial only dependent on one's own theoretical stance, without the need for argumentations and confrontations with other stances. Apart from this, the example of Pritchard et al. (2011) illustrates the uncritical way so-called Critical Theorists in the tourism academy confused this tradition with theoretical elements that are even opposed to it. Using Weber's value-laden research as a characteristic of Critical Theory remains impossible, and creates extra disarray.

The classical thinkers of Critical Theory need to be understood in order to clarify the significance of this tradition in the present situation. In this article two main concepts will be selected from this tradition: the Critical and Essence. In the German discussion between the Critical Rationalism and Critical Theory during the 1960s (the 4th Positivismusstreit), Marcuse introduced the concept of Essence as an answer to his critical rationalist opponents, persistently categorized by him as positivists. We will discuss this concept after its confrontation with postmodernism and relate this discussion to a revitalization of the "Critical," in Critical Theory. We will save this qualification from the postmodernist attacks on the universality of the Critical Theoretical position. We will introduce a mode 3 discussion (Kunneman, 2005; Isaac \& Platenkamp 2012), in which the qualification "Critical" receives a new significance on the "agora" (Arendt, 1958). Arendt introduced the agora as an open/public space, similar to the forum Romanum, which people present themselves as individuals with independent thoughts. The authors' position is that the critical impulse in this theory has experienced a serious degree of content inflation so that everyone in the tourism academia who uses the word critical has become critical. During the Critical Turn in Tourism Studies conference, which took place in Opatja, Croatia in 2015, the authors noticed an inflated use of the word critical almost in all presentations.

The qualification "Critical" will receive a more actualized significance if it can be fully elaborated during the process of the argumentation at the "agora" of the public domain, and Rachel's Tomb in Bethlehem, Palestine will be used as a case study. Rachel's Tomb is a thought-provoking site because of its historical relevance, which was part of Bethlehem's heritage for centuries and due to its location in a disputed region of occupied Palestine, in Bethlehem, characterized by the Segregation Wall and rapid changes of the landscape (Isaac \& Platenkamp, 2016; Selwyn, 2010). The biblical figure of Rachel as a religious matriarch, the second wife of the patriarch Jacob, is an important female icon in Judaism and Christianity, and she is also highly regarded in Islam. As will be illustrated in this case, a leading element of this critical impulse becomes the principle of hope. This article begins by introducing the characteristics of the Critical Theory, in line with what it means to be critical, the concept of essence, and a critical review of totality, dialectics, and essence. This discussion is followed by presenting the polyphonic dialogue where it replaces the concepts of essence in mode 3 discourse, and explaining the modes of knowledge productions, namely mode 1,2 , and 3 (see Fig. 1 later in this review article).

According to Clifford and Marcus (1986) that a dialogue where truth claims of isolated individuals is replaced by a careful process of persuasion in which no voices are excluded (Denzin \& Lincoln, 2000). The critical concept of essence has faded 


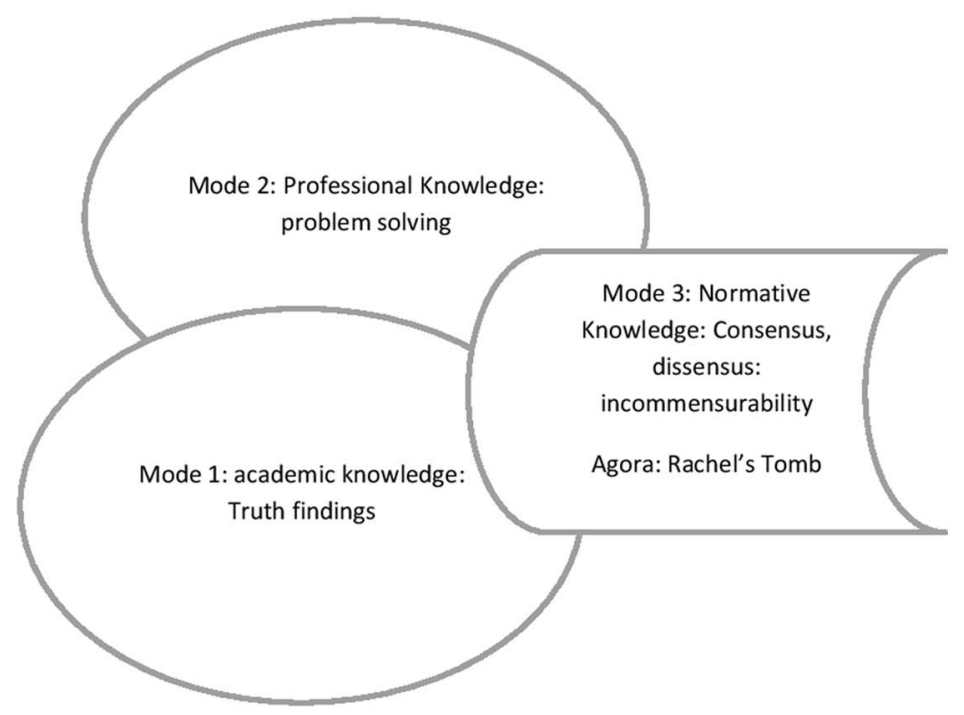

Figure 1. Modes of knowledge production (adapted from Isaac \& Platenkamp, 2012).

away in a relativist manner. Instead of this relativism, the concept of a polyphonic dialogue tries to replace the concept of essence in a nonessential way. The contested heritage of Rachel's Tomb offers a good illustration of how this polyphonic dialogue could play its revitalized role. The final section introduces the history and the changing face of Rachel's Tomb and the revitalization of the qualification "critical” on the agora.

\section{A Characterization of Critical Theory}

Horkheimer (1937) distinguished critical from traditional theory. For traditional theorists a theory was a whole of propositions in a particular discipline that are interconnected in such a way that some of them can be deduced from others. These deduced statements or hypotheses must be empirically tested. In case of contradictions between theory and empirical facts, the statement or the way of perception needs to be revised. The theory will always remain hypothetical in relation to the facts.

From this traditional perspective any theory consists of a construction of mutually interconnected logically consistent hypotheses that do not pretend to understand the data that they want to measure in their "real essence," because this is impossible to verify or falsify. The object of a theory consists of isolated regularities of data and functions. Attempts to know society as a whole, therefore, are useless because selection and abstraction are essential characteristics of our knowledge and our actions.

Although the unity of science remains an ideal in this traditional perspective, science still falls apart in different disciplines with different frames of concepts. Social sciences, hereby, look at the natural sciences as their example. They strive for a-historical, universally valid statements and exclude questions about the societal role of social sciences as not belonging to the field of science. The internal structure of traditional theory does not even allow these questions, as analytical theories only relate to logical-causal laws, to "if-then relations." Knowledge of these relations can be translated into guidelines for action: if we know what consequences certain causes have under particular circumstances, then we can check which means under these circumstances could reach particular goals. Therefore, we can develop social techniques in order to influence social processes with the ultimate limitations that we cannot make a choice of the goals on the basis of these if-then relations. The choice between different goals remains a free, moral choice of the civilians of a state. 
A critical theorist, said Horkheimer (1937), objects to this picture of science that a type of pragmatic rationality has been exchanged for "pure scienticity." What traditional scientists see as the "in principle" unchangeable essence of theory is in fact the expression of a certain (labor) situation in society. Science is not autonomous and independent, but forms a part of the societal production process of which various parts are intricately connected. Facts that our senses infer are prefabricated in society as historical objects that are perceived concomitant to the historical positions of the perceiving subject. A thinking subject in science can never isolate him- or herself from the society and the societal consciousness. And the same goes for a theory. A theory is an utterance of a societal consciousness and can never be isolated from her social role and function. Both are not "naturally given," but constituted by human activity.

Traditional theory separates science from politics. In 2010 the Organisation for Economic Cooperation and Development (OECD) organized a conference on "green tourism" in East Jerusalem; it excluded all political aspects that were related to this topic. As Isaac, Platenkamp, and Çakmak, (2012) stated, the question therefore becomes: is this a message from a "green" paradise or a "declaration of war" against the excluded from the OECD conference? (p. 160). The implication of this separation of politics from tourism science was that the whole political context of (occupied) East Jerusalem has been silenced in the discussion about "green tourism." Another implication of this was the exclusion of many Palestinian and other academics (Isaac et al., 2012).

Horkheimer (1937) commented that in this way the scientist looks at the societal reality (totality) as not crucial and at the most as something that can be dealt with in his free time in his position as a civilian. This dualism of "ought and being" implies that philosophy and politics are excluded from sciences and are made a concern of private life. Whole areas of serious concern are excluded in this way from the rational, scientific discussion and left over to irrational (power) centers of decision making. This split rationality leaves the choice between relevant goals to these power centers and condemns knowledge in this area to a situation of powerlessness. Critical Theory rejects the assumption that the relation between subject and object is neutral and unchangeable. As this theory wants to have influence based on its insights and as its object-society in its totality — changes as a whole, the theory itself has to change with these developments of society itself. The notion of the critical is dependent on this connection with society itself.

Society, according to Horkheimer (1973), is a totality of which the actual shape cannot be separated from history and its tendencies, as they are interpreted by the dialectics of historical materialism. Society as a totality should be changed, as has been demonstrated by the dialectical turns in history, because of its fundamental contradictions that need to be solved. Our modern society, on the other hand, has been able to overcome these contradictions without solving them. Laborers are satisfied with their material conditions without wanting to change their unjustified labor situation, to mention just one of these fundamental contradictions in need for change. Through a cultural mass industry individuals in this late-capitalist society are losing their necessary critical consciousness that would arouse their "revolutionary potential." In his One Dimensional Man Marcuse (1964) described these individuals convincingly. Capitalist society within its fundamental contradictions needs a critical consciousness by groups of people that are experiencing these contradictions the most-exactly such as the labor class. These groups are included and integrated in a materialist consciousness by a cultural mass industry that influences these groups to such a degree that they lose their critical consciousness and celebrates the new materialist blessings. Marcuse, in line with the tradition of the Critical Theory, sees no escape from this dilemma between a necessary solution to these contradictions and the impossibility to have confidence in the groups that should produce this solution. For Palestinians this analysis would lead to the pessimistic conclusion that no social movement would be strong enough to develop a workable critical perspective on the Israeli occupation. In line with this, the Israelidominant interpretations of occupation in general, and of Rachel's Tomb in particular, are fully influenced by the Israeli mass media that effectively presents the conflict in one-dimensional manner, in which of course, Palestinians are too powerless to organize any critical notion that will be taken 
seriously. This pessimistic outlook on society, here applied to the Palestinian situation, has deeply influenced Critical Theory right from its start.

\section{Being Critical and the Concept of Essence}

This lack of a necessary critical impulse has become probably the most important point of orientation during the history of Critical Theory. According to Marcuse (1968), "The rationalist theory is well aware of the limits of human knowledge and of rational social action, but it avoids fixing these limits too hurriedly and, above all, making capital out of them for the purpose of uncritically sanctioning established hierarchies” (p. 15). This critical impulse, which should never lead to "uncritically sanctioning established hierarchies," remains a crucial aspect of Critical Theory in the post-Marcuse era. But Marcuse still embedded this critical impulse in his broader concept of "essence." To understand this concept it is important to situate it in the potential world. A critical consciousness, then, of an actual situation that contains a nonrealized potentiality from this potential or possible world stimulates the search for essence. The tension between potentiality and actuality arouses knowledge that should become part of a practice of change. From what is possible critique emerges on that what exists. The essence, then, is related to the totality of the social evolution. In this particular phase of the evolution this implies that the potential changes are related to what can be organized in this particular historical period as it fits into this evolution. The totality of a social process is always situated in a historical context that is part of the social evolution of human mankind. In this totality or essence the remembrance to all battles for justice delivered has been assembled. The core issues of these battles are situated on an economic level. In this sense Marcuse is obviously Marxist in his outlook. Economy and its evolutionary phases is considered to be the essential level and the other-political, social, cultural, etc.-levels are its manifestations and the relation between this economical level and its manifestations is dialectical.

This so-called remembrance of all these historical battles has a dialectical relation with what still can be realized, which causes the motivating idea in the practice of change. That is why modern laborers who have lost their revolutionary potential have developed a false consciousness because of which they have lost their critical impulse to change their own repressive, socioeconomic circumstances. It is possible to speak of a false consciousness because the (total) truth lays in the concept of essence as explained. But what if this false consciousness remains dominant without any critique? For example, in Palestine false consciousness can be seen as the uncritical acceptance of the Israeli occupation by Palestinian groups (especially in Israel) that are influenced by the Israeli mass media. Their understanding of the conflict is dominated by the Israeli interpretations, without critical reflection.

Adorno and Horkheimer (1947) referred to the blindfolded rule that represents the interests of some dominant individual groups, but has been taught to us as a justified whole (totality). Thus, particular interest of the elite has been presented as the universal interest of a society as a whole. For example, nationalism has been presented as a justified totality, whereas in fact it represents the interest of dominant elites and is successfully presented as relevant for the whole society. That is why Adorno and Horkheimer claimed that a critical consciousness should return to its truthful spirit, which tries to reconcile itself with true nature. Out of this reconciliation it appears what rationality means for them. They look at rationality as the realization of happiness for society (la promesse de bonheur) in its totality. In other words, when a civilization process is blind, this would mean that it is taking place in an irrational manner, because it does not connect to this rational destiny of the totality. Nationalism, in this argumentation, is referring to an irrational totality and a false consciousness of the dominant groups in a society. Exactly this was taking place at the moment. The world still is developing in the direction of a total, controlled world and people are surrendering to this world without any resistance. This was the message from Adorno and Horkheimer. In Palestine, this would mean that this concept of truth and rationality would completely exclude any possible critical resistance. If we would accept this conclusion, Rachel's Tomb would remain without any critical opposition.

Popper criticized this all-pervading pessimism because it: "aus der Enttauschung über das Scheitern allzu weit gespannter utopischer oder revolutionarer 
Hoffnungen notwendig entspringen müsse” (Dahrendorf, 1962). In English this means: From the disappointment about the failure of this too tensely tied utopian or revolutionary hope this pessimism seemed logical.

A Critical Review of Totality, Dialectics, and Essence: Polyphonic Dialogue as an Alternative

A rational totality has been criticized in many publications (e.g., Adorno, 1972; Platenkamp \& Botterill, 2013) as an impossibility. Reality cannot be understood as a totality. Even dialectics cannot make that happen. The claims of dialectics in "neoMarxism” as a total, all embracing instrument of rationality have been dismantled enough among others by postmodern relativism. On the other hand, this does not mean that dialectics as an instrument does not have any practical use. Many thought processes seem to have a dialectical movement in them and it may be handy to use dialectics in some situations as a way of structuring these processes. However, its rational claims must be rejected because of the analytical claim of formal logics that the rejection (antithesis) of a hypothesis (thesis) "in principle" should have consequences for the truth claims of any theory. The synthesis, then, becomes the ultimate way of escaping this rejection, the phase of dialectics in which the immunization of critique has been fulfilled.

In this sense the tradition of Critical Theory can be called a monistic tradition, due to its one sidedness. Reality has been deduced in its totality from a certain amount of core (essential) assumptions. The critique from a pluralist vision on reality as being approached by a diversity of perspectives that are in a constant disagreement has proven to be stronger in recent, postmodern times. Postmodernity itself has been strongly influenced by the fall of the iron curtain and the end of the ideologies in recent world history. Dialectics has been included in this postmodern critique, also in nonscientific publications. Solzenytsin (1974), in his novel The Gulag Archipelago, already offered a good example. With his anti-Marxist (and antidialectical) position, among others, he had a strong influence on the dominant intellectual left framework of France. An amusing example comes from Zinovjev (1976), who described a political instruction in the Soviet Union where the instructors explain dialectics at a moment during the Second World War that the Russians are pushed into their inlands by the German enemy. A stupid pupil in this instruction class, who does not understand dialectics at all, stands up, when he hears this news, and exclaims: "Hurray!! In panic the rival is fleeing behind our troops!” After this statement the pupil has been removed to a Soviet concentration camp, the writer says. The conclusion of this story: if the freedom of contradiction will be abolished by understanding any contradiction dialectically one can say anything under the wings of rational truth and denying the truth equals denying an earthquake. Critique becomes worthless unless understood by the right and only principles that cannot be doubted. But exactly these right and only principles have been severely attacked in recent decades. The concepts of essence and dialectics, for example, have disappeared from the major approaches of Critical Theory in recent days, mainly due to postmodern influences (Bauman, 1994; Benhabib, 1996; Vattimo, 1991).

The total concept of rationality has been criticized effectively, most recently by postmodern thinkers. However, the tension between a potential world and actuality remains relevant and refers to a possible way of reformulating the critical impulse of Critical Theory without its total and dialectical pretensions. It remains crucial to "avoid fixing the limits (of rational critique, too hurriedly and, above all, making capital out of them for the purpose of uncritically sanctioning established hierarchies" (Marcuse, 1968, p.15). Critical Theory always will point to the fact that theorizing about our society itself has to be theorized from a critical and societal (power) perspective. Any social analysis is embedded in society and Critical Theory has persuasively developed its frames to include this embeddedness in its analyses. If this will be excluded established hierarchies will succeed in representing their interpretations of social reality as the only justified ones without critique. Horkheimer's (1937) critique on traditional theory in this sense remains actual and the most relevant question is how to organize the critical impulse that stems from it after the justified, postmodern attacks on the total rationality of Critical Theory. In the everyday life of Palestinians as anywhere else in the world, pluralist critique will always remain alive. Positions will be taken and the 
need for critical debate between these discussions on the "agora" will be felt. The Tourism Studies "academia" settled on the legacy of Critical Theory sometimes after its zenith in the social sciences in the 1960s and 1970s. It does so, therefore, carrying the current of contemporary environment that surround Critical Theory. A series of seven biannual conferences of a newly formed critical tourism studies community has been organized in different places in the last 10 years. Methodologies were applied in a criticalist manner with examples from Grounded Theory, Constructionism, Ethnomethodology, diary and memory-work from Feminism, oral history, and life course analysis (see, here, the special issue of Tourism Analysis on Critical Tourism Studies, i.e., Causevic, Minnaert, Morgan, \& Pritchard, 2018). These legacies of Critical Theory were positioned alongside news streams of thought such as postmodernism, poststructuralism, deconstructionism, and postcolonialism, despite the often serious points of difference between them and mainstream "Frankfurt School" thinking that initially inspired Critical Theory (Botterill \& Platenkamp, 2012). This eclectic mix within the critical tourism community caused an inflation of the content the qualification "critical." The term critical always has been associated with a thorough reflection on potential developments in society, which promise a better future. This reflection contains probably the most serious part of what Critical Theory aimed at. In this eclectic mix this type of reflection has become more and more scarce.

Kolakowski (1978) wrote a classical study on this content inflation of the term critical within neo-Marxist currents like Critical Theory, and the critical tourism community has not been an exception. In this article, it is claimed that the term critical needs a new reflection on its content. Therefore, a polyphonic dialogue will be introduced to reanimate this critical impulse.

If the concepts of totality, essence, and dialectics do not suffice anymore to guarantee the critical impulse of Critical Theory, where could we find this foundation. Habermas (1984), maybe the last serious but non-Marxist representative of Critical Theory, has shown us the direction. His reputation as the last influential theorist of the Frankfort School is without discussion. His communicative action opens the possibility of criticizing phenomena as they are embedded in actual, systemic power relations. The tension between potentiality and actuality that has been formulated by Marcuse in relation to the concept of essence has been actualized by Habermas through his communicative action. In his concept of communicative action he has been influenced by Arendt's “agora” (Arendt, 1958; Kunneman, 2005), and for good reasons. Arendt proposed the agora as an open public space, similar to the Forum Romanum, on which individuals present themselves with independent opinions and thoughts. Arendt entered a web of human interrelationships-like in the Greek agora or in the Roman res publica - that supports the idea that men make their appearance in the human world by the disclosure of themselves as active agents in the reality in between people of this web. This world becomes human because through speech and acts the human animal succeeds in creating a world that exceeds the daily demands of biological survival and the fabricated world of the homo faber. In this way, pluralized discussion and debate come into being that create the opportunity for individuals to present themselves as human beings. On the agora the critical impulse receives its necessary and actual power. Plural voices are given the opportunity at the agora to present themselves. Consensus is not the self-evident outcome of the discussions that take place, here, in an open and critical manner. Participants need to bear contradictions also when they lead to dissensus. Open and critical discussions are self-evident in this polyphonic dialogue (Clifford \& Marcus, 1986) and warrant what is left of the critical impulse of the Critical Theory. The much debated concept of essence and the truth claim that has been related to it has seriously suffered from the attacks of postmodern critique and could, therefore, now be replaced by this concept of a polyphonic dialogue on the agora. This dialogical rationality could become the basis for a renewed critical impulse of Critical Theory, which has lost her old basis.

The distinction between mode 1, 2, and 3 (Gibbons et al. 1994; Isaac \& Platenkamp, 2012; Kunneman, 2005; Tribe, 1997) in the production of knowledge helps us to articulate this renewed critical impulse in a more structured manner. In order to come up with a clear picture about moral and existential discussions in relations to Rachel's Tomb, mode 3 
discussion has been added to the analysis; therefore, all modes of knowledge will be introduced here.

\section{Knowledge Production: Modes 1, 2, and 3}

From a historical (Western) perspective globally three phases can be distinguished in the production of (tourism) knowledge. First of all these three phases are based on the relations between academic, professional, and normative and more philosophical knowledge. Gibbons et al. (1994) debated the transformation in knowledge production as a global phenomenon and distinguished between mode 1 and 2 knowledge production. Since the end of the 20th century and alongside "traditional" modes of knowledge production (mode 1 knowledge production), a mode 2 knowledge has emerged and created a broader, transdisciplinary (social and economic) context of application. For example, for mode 2 knowledge production during the 1990s in the last century has been a revolutionary contribution to the knowledge development in the applied context of Information Communication and Technology by many stakeholders (Tribe, 1997). It has been called mode 2 knowledge because the authors judged the conventional terms such as applied science, technological research, or research development as inadequate. It is a fresh production of knowledge that has a strong influence on the dominating image of scientific knowledge that has always been interpreted as mode 1. Tribe (1997) and Portegies, de Haan, \& Platenkamp (2009) used this distinction in the area of tourism studies. Coles, Hall, and Duval (2009) labeled the distinction as follows: "Mode 1 appears to be the dominant type in higher education these days, as 'the traditional centre for knowledge production,' whereas mode 2 was originally anticipated as taking place outside university structures” (p. 84). From a critical theoretical perspective, normative rationality has been excluded from mode 1 and 2 discussions. There has been a tendency in late capitalist society to stress the concept of instrumental rationality in mode 1 and 2 knowledge production. Mode 3 knowledge production contains the attempt to revitalize this normative rational discussion. Where Critical Theory speaks about essence dialectics and totality, the main intension is to develop normative directions for a better future. This critical intension has been replaced in this article by a polyphonic dialogue on the agora, which produces a mode 3 type of knowledge (Fig. 1).

\section{Why These Modes?}

Kunneman (2005) introduced mode 3 knowledge in the awareness that during the second phase in both other modes there has been a long-term trend to exclude the "slow questions," related to sickness, death, and repression but also to moral virtues as compassion, inner strength, or wisdom and other sources of existential fulfillment that remain crucial for all generations in a variety of places. Kunneman (2005) called inter alia for a relatively autonomous contribution of the treatment of these slow questions to professionalism at large. There are two ways of tourism knowledge production connected in mode 2 in order to find adequate solutions for specific, context-related problems: on the one hand the objectifying knowledge of mode 1 , and on the other hand the existentially and morally laden values that are codeterminant for organizing these solutions in mode 3 . Knowledge production in mode 3 is related to the influential character of these values and frames of meaningful interpretations of the questions and problems in the contexts of application in mode 2 (Isaac \& Platenkamp, 2012). In postindustrial societies there are satisfactory available sources for the transformation of mode 1 knowledge into mode 2. This is not so much the case with mode 3. Economic and political power constellations (strategic action), but also dogmatically defended frames of interpretation, constitute obstacles to the necessary development of the learning processes in this mode. Consequently, it becomes more important to stimulate a relative autonomous development of mode 3 that supports more adequate interferences in tourism professional practices. A crucial feature for the argumentation structure of mode 3 is that consensus between positions can be, but does not need to be, reached. Dissensus is as possible as consensus and incommensurability-the logical disconnectedness of different positions-is a necessary condition in this mode (Isaac \& Platenkamp, 2012). In this manner, we might be able to revitalize the "critical," on the agora through a mode 3 discussion, in the public domain. How this can be elaborated 
will be illustrated by the case of Rachel's Tomb in Bethlehem.

\section{The Changing Face of Rachel's Tomb in Bethlehem, Palestine}

Rachel's Tomb is an interesting site study due to its historical relevance and because of its location in a contested area of occupied Palestine, in Bethlehem, characterized by the Segregation Wall (Isaac, 2009) and rapid changes of the landscape. Consequently, cultural heritage in this space cannot be abstracted from the tension in its societal background and the power relations that go with it. That is why the qualification critical is extremely relevant in this case study.

Rachel is a biblical figure as a religious matriarch, the second wife of the patriarch Jacob, is a significant female icon in Judaism and Christianity, and she is also immensely regarded in Islam. Muslims considered the site sacred for its relation to Abraham and thus kept its keys. Her dramatic story mostly told in the Book of Genesis (Genesis 25-49, cited in Aghazarian, Merli, Russo, \& Tiemann, 2010) has impressed generations of Christianity and Jewish believers for several causes. First, her love story with Jacob, and second her connection with her sister Leah with whom she shared her husband, her finally being able to conceive and in the end, her death while giving birth on the way to the land of Isaac's home, in Hebron (Aghazarian et al., 2010).

For several hundred years Rachel's Tomb was located in Bethlehem and it is one of Bethlehem's important historical heritage sites and a part of the city's heritage. The district around the Tomb, known today in Arabic as Qubbet Rahil, covered $11 \%$ of the area metropolitan Bethlehem and was, until fairly recently, one of the economic hub centers of the city. The ancient highway between Jerusalem and Hebron ran through it. Rachel's Tom area had a number of fashionable cafés, restaurants, and shops catering for tourists, Palestinians as well as Israelis (Isaac, 2013; Selwyn, 2010). Subsequently, after the outbreak of the second Intifada (uprising) in September 2000, Qubbet Rahil began to witness some alteration. First, the Israeli military prevented Christians and Muslims from visiting Rachel's Tomb, in violation of the right to worship and limited the shrine to Jewish groups, in a major step to annex the Tomb to Jerusalem. Second, in June 2002, Israel decided to develop a Segregation Wall between Israel and Palestine in order to prevent the uncontrolled entry of Palestinians into Israel (Isaac, 2009, 2013). This Segregation Wall has cut the historical road that links Jerusalem to Bethlehem and Hebron in the south. In the past a vibrant open city, it has been reduced to a ghetto beset by poverty, immobility, and isolation, and separation from the rest of the world (Selwyn, 2010). And finally, the Israeli authorities issued an order to seize lands north of Bethlehem to construct the Segregation Wall that would annex the area of Rachel's Tomb to Jerusalem. The Israeli authorities then revealed that 18 dunums (4.5 acres) (a dunum is approximately one quarter of an acre) of land were scheduled for confiscation, mainly for the route of the Segregation Wall, while at the same time segregating another 3000 dunums (750 acres) of agricultural lands planted with olive trees behind the Wall (Isaac, 2013).

The entire area, currently mapped for Segregation, contained 40 residential buildings with a total of more than 500 Palestinian inhabitants, and furthermore, a number of commercial stores, restaurants, souvenir shops, maintenance shops, and gas stations (Applied Research Institute, 2005).

In 2005, as a result of the expropriation of Rachel's Tomb by the Israeli military, they built multiple Walls and armed watchtowers around and near it, and declared it part of the Israeli municipality of Jerusalem in 2010. In this course of development, the whole area has effectively been destroyed, the majority of its inhabitants have left the area, and its business has been closed down (Kousis, Selwyn, \& Clark, 2009). Today, buses full of (Jewish) tourists and visitors travel from Israel just to the place where Rachel's Tomb has been confiscated by the Israeli interpretation of this cultural heritage, physically protected by the Segregation Walls (Fig 2).

Of course, mentally, the primarily Israeli perception of these tourists has been protected through the exclusion of the Palestinian Muslim and Christian interpretations of Rachel's Tomb. The systematic patterns of political and symbolical repression, manipulation, and oppression that constitute the hidden logic of this Zionist interpretation refer to a situation of colonization, apartheid, and racism 


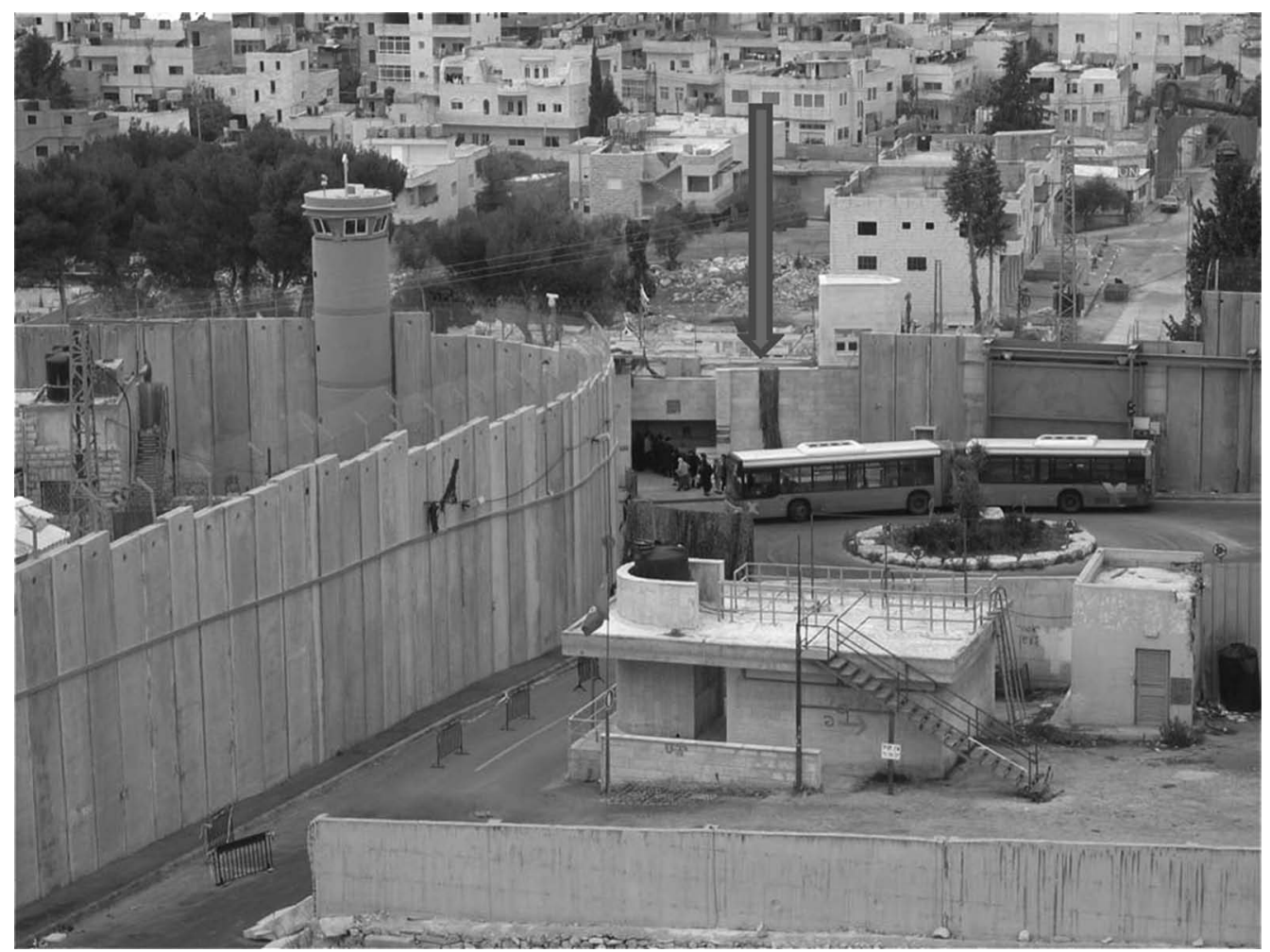

Figure 2. Rachel's Tomb, segregated. (authors' photo).

(Isaac \& Platenkamp, 2016). Instead of concepts of totality and dialectics, we focus on hope as the core element. On a daily basis, we see that still Palestinians have hope, despite of the oppression, and mechanisms of occupation. People still have hope, that one day there will be an end to this colonization and oppression, and to the occupation in all its facets. It has been clearly clarified that hope for social justice is obviously related to the needed revitalization of the critical impulse within critical thinking. This revitalization clearly is related to the success or failure of mode 3 pluralist discussions on the agora in Palestine, which can give a voice to the everyday opinions of Palestinians on these topics. This mode 3 debate stimulates the necessary hope in people's lives.

\section{Revitalization of the Critical: Rachel's Tomb}

Actual interpretations are dominated by the Israeli frame of reference (Higgins-Desbiolles, 2016; Isaac, Hall, \& Higgins-Desbiolles, 2016). In order to revitalize the idea of potentiality as a basis of critique, the other relevant traditions should become equal partners in the polyphonic dialogue, to the Israeli frame of reference. In this manner, the critical receives a revitalized content. From a situation where the critical has been completely eliminated by the dominant Israeli interpretations as well as the confiscation of Rachel's Tomb, to a situation in which some hope has been stimulated through a consequent polyphonic dialogue about these topics. The need for this hope can only be fulfilled through a revitalization of the necessary critical dimension.

The actual situation around Rachel's Tomb can be characterized by the dominant Israeli interpretations. As a result these are the current implications on the whole area:

- Dominant Israeli Interpretation: By excluding Palestinian Muslims as well as Christians from visiting the site, the Israeli interpretation of the cultural heritage of Rachel's Tomb has been dictated as the only one by the exclusion of 
the Palestinian, Christian, and Islamic interpretation (Selwyn, 2010). This exclusion has been intensely reinforced through the position of the Segregation Walls on the occupied territories around Bethlehem.

- Confiscating more Palestinians' land from the Rachel's Tomb area as a result of the Segregation Wall: Rachel's Tomb was part of a tourism metropolis where all interpretations had space. Today, after the construction of this Segregation Wall, Rachel's Tomb has been isolated physically from the rest of its environment through the position of the Wall with only tourists from Israel visiting this heritage now exclusively confiscated by Israel.

- Destroying the Economic (Tourism) Centers of Metropolitan Bethlehem: As previously mentioned the neighborhood around Rachel's Tomb, known today in Arabic as Qubbet Rahil, comprised $11 \%$ of the area metropolitan Bethlehem and was one of the economic hubs of the city. The ancient highway between Jerusalem and Hebron ran through it. The area had a number of fashionable cafés, restaurants, and shops catering for tourists, Palestinians as well as Israelis.

- The majority of its inhabitants have left the area and its business has been closed down: In this course of development and the construction of the Segregation Wall, the whole area has effectively been damaged, the majority of its inhabitants have left the area and its businesses have been closed down.

The trouble with Rachel's Tomb and its surrounding is that it is (they are) part of a more allencompassing issue in Palestine in which Jewish settlements and settlers are enclosing Palestinian towns and cities such as in Bethlehem. The Israeli authorities' expropriation of Rachel's Tomb, which included building of walls and armed watchtowers around it, declared it part of Israeli municipality of Jerusalem.

In order to disapprove this dramatic situation, a situation of despair, dialogical rationality is needed to organize and create a potential domain of criticality on the agora. These types of dialogue can function as a catalyst to the enhancement of the process of self-examination. The creation of hope and meaning that is involved in this process and that needs a place for development in this overwhelming cynical situation.

For example, the so-called Alternative Tourism Group (ATG), a Palestinian nonprofit organization located in Bethlehem, invites prominent Palestinian academics as well as Israeli institutions that deal with the occupation of Palestinian lands and the implications of it, to present the tangible as well as the intangible characteristics of the oppression, and the control of the Israeli military regime in Bethlehem. The purpose of these meetings is to create awareness among inhabitants, visitors, and tourists. But at the same time, Palestinian guides working in this field also become aware of the situation and are more inclined to train the new roles that go with. For example, Palestinian guides can also touch upon these issues of the Israeli occupation, the annexation of Rachel's Tomb, and the destruction of Rachel's Tomb area, as a center of economic hub that used to be in Bethlehem. Via this growing awareness among the Palestinians, the hope for a better future could become a reintegrated part of the Palestinian mind-set. It could lead to a new perspective of resistance against the existing power relations. It opens Palestinian minds and makes them realize that no human being has to accept this humiliating condition in their everyday lives. Another activity on the agora is the organization of lectures, documentaries, by Palestinian as well as Israeli historians in order to raise the nonviolence resistance and struggle against the injustices committed by the State of Israel in general and particularly in the case of Rachel's Tomb area. Based on these activities, fruitful discussions are stimulated among different groups that have interest in this actual situation. In this way, hope will be kept alive on a better, potential situation.

In recent years, a so-called "Wall Museum" of posters has been created on the Segregation Wall near Rachel's Tomb in Bethlehem, Palestine. As an initiative of the Sumud story house (Fig. 3) of the Arab Educational Institute, it is designed to communicate real-life Palestinian women's stories. The stories of suffering and oppression, "Sumud" (steadfastness or resilience), inner strength, and cultural identity are chosen to bring out the truth of Palestinian life, which the Wall tries to hide and kill (personal communication with T. Van Teeffelen, April 2014). 


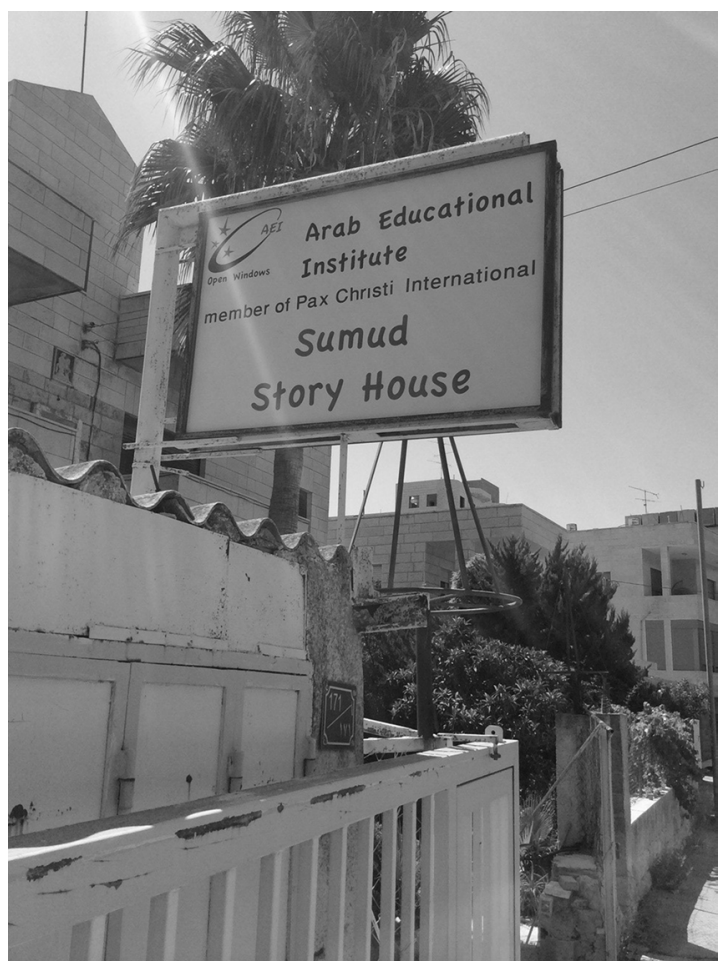

Figure 3. Sumud House, near Rachel's Tomb (authors' photo).

They are written or chosen by Palestinian women's groups who convene at the Sumud Story House. The project is made possible through sponsorship of individual posters. Visitors of Bethlehem are invited to visit the museum. Through individual sponsorship, the "museum" will gradually expand. The Sumud Story house is part of the Arab Educational Institute in Bethlehem, affiliated to Pax Christi. Arendt introduced the agora as a public space. This space of dialogue does take place at the Sumud house, and has the potentiality to create hope, even in such a desperate situation.

\section{Conclusion}

In the last post-Marxist decades Critical Theory has been heavily and partly successfully attacked by postmodern and anti-ideological thinking. The concepts of totality, essence, and (Hegelian) dialectics did become problematic. This implied a serious degradation of, among others, the qualification "critical" within the context of what was left of Critical Theory. Critical Theory has been referred to in the tourism academy in a rather chaotic manner. This situation also became dominant in the tourism academia. The eclectic mix of various positions within the critical tourism community is characteristic of the loss of significance of the qualification critical, which became evident in a number of the Critical Tourism Studies international conferences. The need for revitalization of the critical impulse has become urgent in this context. By reintroducing the tension between the actual and the potential and by stressing a pluralist and dialogical rationality on the "agora" (Arendt, 1958) this critical impulse has been revitalized in this article. The situation of Rachel's Tomb in the context of the Israeli-Palestinian tensions served as an illustrative case of how this critical impulse still proves its additional value from a changed critical theoretical perspective, on the "agora" of the Middle East. Dialogical rationality is needed to organize and create a potential domain of criticality on the agora. These types of dialogue can function as a catalyst to the enhancement of the process of self-examination. The creation of hope and meaning that is involved in this process and that needs a place for development in this overwhelming cynical situation.

The effort to organize a polyphonic dialogue between unequal parties that are forced to take equal positions on the agora has become a new way to become critical, in this extremely desperate situation. The principles of hope, which always has been a crucial element in critical thinking, becomes actualized through this dialogue. It could lead to a new perspective of resistance against the existing power relations. It opens the Palestinian minds and makes them realize that no human being has to accept this humiliating condition in their everyday lives as well as the annexation of Rachel's Tomb. There is a strong need for this dialogue from within the lifeworld of Palestinians and Israelis in order to create a better future. This thought about the future contains a critical reflection on existing power relations in combination with a justified peace in the region.

\section{References}

Adorno, T. W. (1972). Der Positivismusstreit in der Deutschen Soziologie Ulm. Munich, Germany: Hermann Luchterhand. 
Adorno, T., \& Horkheimer, M. (1947). Dialektik der Aufklärung. Frankfurt, Germany: Fischer.

Aghazarian, E., Merli, A., Russo, L. M., \& Tiemann, I. (2010). Rachel's tomb: An alien in her hometown? Perceptions from the other side of the Wall. Berlin, Germany: Aphorism Verlag.

Applied Research Institute. (2005). The Israeli assault on Bethlehem triangle. Jerusalem: Author.

Arendt, H. (1958). The human condition. Chicago, IL: The University of Chicago Press.

Bauman, Z. (1994). Postmodern ethics. Oxford, UK: Blackwell.

Benhabib, S. (1996). Democracy and difference. Contesting the boundaries of the political. Princeton, NJ: Princeton University Press.

Botterill, D., \& Platenkamp, V. (2012). Key concepts in tourism research. London, UK: Sage.

Causevic, S., Minnaert, L., Morgan, N., \& Pritchard, A. (2018). Prospect: The future of Critical Tourism Studies. Reflections on the road ahead. Tourism Analysis, 23, $\overline{177}-181$.

Clifford, J., \& Marcus, E. (1986). Writing culture. The poetics and politics of ethnography. Los Angeles, CA: University of California Press.

Coles, C. Hall, C. M., \& Duval, D. T. (2009). Postdisciplinary tourism. In J. Tribe (Ed.), Philosophical issues in tourism (pp. 80-100). Bristol, UK: Channel View Publications.

Dahrendorf, R. (1962). Anmerkungen zur Diskussion der Referate von Karl R. Popper und Theodor W. Adorno, Kölner Zeitschrift für Soziologie und Sozialpsychologie XIV, 268/269.

Denzin, N., \& Lincoln, Y. (2000). Introduction: The discipline and practice of qualitative research. In N. Denzin \& Y. Lincoln (Eds.), Handbook of qualitative research (2nd ed.). Thousand Oakes, CA: Sage.

Gibbons, M., Limoges, C., Nowotny, H., Schwartzman, S., Scott, P., \& Trow, M. (1994). The new production of knowledge. London, UK: Sage.

Habermas, J. (1984). Theorie des kommunikativen Handelns. Frankfurt, Germany: SuhrkampVerlag.

Higgins-Desbiolles, F. (2016). Walled off the world. Palestine, tourism and resisting. In R. K. Isaac, C. M. Hall, \& F. Higgins-Desbiolles (Eds.), The politics and power of tourism in Palestine (pp. 178-194). London, UK: Routledge.

Higgins-Desbiolles, F., \& Whyte, K. (2013). No high hopes for hopeful tourism. A critical comment. Annals of Tourism Research, 40, 428-433.

Horkheimer, M. (1937). Traditionelle und kritische. Leipzig, Germany: Leipzig University Press.

Isaac, R. K. (2009). Alternative tourism: Can the segregation wall in Bethlehem be a tourist attraction? Journal of Tourism, Hospitality Planning and Development, 6(3), 247-254.
Isaac, R. K. (2013). Palestine: Tourism under occupation. In R. Butler \& W. Suntikul (Eds.), Tourism and war (pp. 143-185). London, UK: Routledge.

Isaac, R. K., \& Platenkamp, V. (2012). Ethnography of hope in extreme places: Arendt's agora in controversial tourism destinations. Tourism, Culture and Communication, 12(2-3), 173-186.

Isaac, R. K., \& Platenkamp, V. (2016). Concrete U(dys)topia in Bethlehem: A city of two tales. Journal of Tourism and Cultural Change, 14(2), 150-166.

Isaac, R. K., Hall, C. M., \& Higgins-Desbiolles, F. (Eds). (2016). The politics and power of tourism, in Palestine. London, UK: Routledge.

Isaac, R. K., Platenkamp, V., \& Cakmak, E. (2012). Message from paradise: A critical reflection of the tourism academy in Jerusalem. Tourism, Culture \& Communication, 12(2-3), 159-171.

Kolakowski, L. (1978). Main currents of Marxism: Its origins, growth and dissolution. Oxford, UK: Oxford University Press.

Kousis, M., Selwyn, T., \& Clark, D. (Eds.). (2009). Contested Mediterranean spaces: Ethnographies essays in honour of Charles Tilly. Middlesex, UK: Middlesex University Press.

Kunneman, H. (2005). Voorbij het dikke-ik Amsterdam, Netherlands: B.V. Uitgeverij SWP.

Marcuse, H. (1964). One dimensional man. Boston, MA: Beacon Press.

Marcuse, H. (1968). Negations. Essays in critical theory. Boston, MA: Beaca Press.

Platenkamp, V., \& Botteriell (2013). Critical realism, rationality and tourism knowledge. Annals of Tourism Research, 41, 110-129.

Pritchard, I., Morgan, N., \& Ateljevic, I. (2011). Hopeful tourism: A new transformative perspective. Annals of Tourism Research, 38(3), 941-963.

Portegies, A., de Haan, T., \& Platenkamp, V. (2009). Knowledge production in tourism. The evaluation of contextual learning processes in destination studies. Tourism Analysis, 4, 523-536.

Selwyn, T. (2010). Ghettoizing matriarch and a city: An everyday story from the Palestinian/Israeli borderlands. Journal of Borderlands Studies, 24(1), 39-55.

Solzenytsin, A. (1974). The Gulag Archipelago. Glasgow, Scotland: Collins/Fontana.

Tribe, J. (1997). The indiscipline of tourism. Annals of Tourism Research, 24(3), 638-657.

Vattimo, G. (1991). The end of modernity: Nihilism and hermeneutics in post-modern culture. Baltimore, MD: John Hopkins University Press.

Zinovjev, A. (1976). Gapende Hoogten. Amsterdam, Netherlands: Meulenhoff. 
Copyright of Tourism Analysis is the property of Cognizant, LLC and its content may not be copied or emailed to multiple sites or posted to a listserv without the copyright holder's express written permission. However, users may print, download, or email articles for individual use. 